\title{
INDIRECTNESS AND INTERPRETATION IN AFRICAN AMERICAN WOMEN'S DISCOURSE
}

\author{
Marcyliena H. Morgan
}

\section{Introduction*}

The study of the language behavior of African Americans has resulted in a tremendous body of research detailing various aspects of both the linguistic and metalinguistic workings of the community. Indeed, analyses of African American communication styles (cf. Kochman, 1972, 1981; Abrahams, 1970, 1976) as well as descriptions of the linguistic structure of African American English (cf. Wolfram, 1969; Baugh, 1979; Labov, 1972) have netted a wealth of information about the community while providing fertile territory from which sociolinguistic theory has advanced. Concomitant with descriptions of African American language behavior have been considerable discussion and debate on the role of Africanisms in the development of the language, culture and social reality of African Americans. These discussions have been ongoing for a quarter of a century and focus on whether the language of the community largely results from archaic forms of English, universal rules of language change or African languages. ${ }^{1}$ A recent addition to the origin debate is the argument (Bailey and Maynor, 1987; Labov, 1985) that the language of urban African America is diverging from that of other American English varieties and this divergence is in the form of language innovations which have no apparent historical link to previous African American varieties. 2

Though the study of African American English (AAE) has resulted in detailed descriptions of the dialect, most of the data which contributed to its analysis were gathered from young African American males, at a time when the center of their participation in the community was in the urban street sub-culture. Although Mitchell-Kernan (197i) included women in the body of her work on African American culture and 
communication style, it was nearly twenty years (cf. Morgan, 1989; Bailey and Maynor, 1987) before intergenerational data and women's speech were again systematically collected and included in the study of urban language behavior. Consequently, though African American speech has been vividly described, its description has suffered from constant comparisons to other U.S. dialects and a proclivity for one small segment of the community - adolescent men involved in street culture. While it is indisputable that interesting analyses of the similarities and differences between African American and other U.S. speech styles have emerged (cf. Kochman, 1981), an unfortunate outcome of this narrow focus has been the treatment of the speech and linguistic repertoire of the community as different from and not connected to other African American styles of interaction and norms of communication. ${ }^{3}$ As a result, the speech community, with its requisite exchanges and negotiations, has not been analyzed as a cultural system with an accompanying semiotic system which communicates ideology and a theory of reality (cf. Duranti, 1988; Geertz, 1973; Volosinov, 1973).

This paper addresses this omission by exploring the metalinguistic devices employed in the African American community to represent its identity and social reality. The analysis was accomplished through an examination and intergenerational comparison of the language behavior and communication style of three generations of African American women between the ages of eighteen and seventy-two residing in Chicago between 1974 and 1982 .

The study of the linguistic and communication styles of women is central to the understanding of how the community expresses its reality because women have historically been responsible for the language development of their children and therefore their community. Moreover, African American women have functioned as heads of households either financially or in response to political and social conditions which have required the absence of their men. Not surprisingly, these women represent a collective survival wisdom which has shaped the community's character. They have helped construct and maintain a language and communication system which has reflected two opposed and separate realities: that of a helpless and hopeless slave and ex-slave and that of a responsible and thoughtful human being. The emergence of this dual reality can be traced to slavery; and the roots from which this communication system has grown are planted in Africa. 


\section{Counterlanguage}

In Morgan (to appear; 1989), I describe the life of a slave in the U.S. as one where all civil rights were denied as well as the right to demonstrate any of the attributes of responsible adults: grown men and women were treated as helpless children. As part of resistance to this "slave reality", an alternative reality developed among slaves which allowed them to express a positive self-view as men and women capable of responsibility and control. This hidden, yet selfaffirming belief was a conscious attempt to provide alternatives that could exist and thrive within the confines of the social reality of slavery. Because there were few significant social and political changes after slavery's end, it was necessary for ex-slaves to continue the expression of the dual reality long after the formal institution of slavery was dismantled.

As Bryce-LaPorte (1971) demonstrates, the world of the U.S. slave and ex-slave developed into a classic example of Goffman's (1961) 'total institution'. It was a world established to care for persons felt to be incapable and harmless or incapable but unintended threats to the community; and it was established to pursue work-like and instrumental tasks (Goffman, 1961:4-5). According to Goffman, since the reality of a total institution is defined by those outside it, an underlife or antisociety develops which is counter to the reality of the institution and a communication system often emerges to support this underlife. Halliday (1978) describes this communication system as a means of realization of a subjective reality which does not merely express this reality but actively creates and maintains it. The language is secret and values are defined by what they are not. ${ }^{4}$

As a total institution, U.S. slavery demanded that slaves exhibit behavior in the presence of whites which supported its paternalistic and humanitarian rationalizations. This "looping" (Goffman, 1961), which required that both action and attitude demonstrate participation in the total institution, was reinforced through a communication style imposed on slaves which interpreted any expression of ideas, direct eye contact, or simple questions as potentially aggressive acts. Within this repressive and regimented communication environment, slaves in the U.S. developed an intra-group system of communication unfamiliar to their enslaver. This second level of communication, here referred to as "counterlanguage", has to do with the development of a speech economy in which "ways of speaking" inherited from Africa were reshaped by the historical experience of African Americans in the U.S. 
(Abrahams and Szwed, 1983: Levine, 1977). In the counterlanguage, as in many speech communities in Africa and Africa America 5, the notion of speaker responsibility is essential and hearers and overhearers have as much, or more, "say" in determining a speaker's intention as the sender of the message. For example, Hunter (1982) and Saah (1984), report that in both Hausa and Akan societies respectively, the role of the audience in determining intentionality and speaker responsibility in discourse is so important that figurative language and spokesmen are used to protect the speaker from an unintended interpretation.6 Fisher (1976) and Reisman $(1974 ; 1970)$ report that in the caribbean, addressing remarks to (or about) a person within his/her hearing but through a "sham receiver" is a common practice. " The speaker, avoids responsibility for the audience's assignment of intentionality by obviously and strategically providing conflicting symbols
and signs.

In Africa and the Caribbean, indirect communication occurs in contexts and within norms which all members of the society recognize as appropriate or inappropriate. The norms and style of indirect communication assume a different character in the U.S. because indirect communication has historically served counterlanguage functions and is therefore neither practiced nor known by the entire society. It symbolizes a reality and ideology that, while part of Africa and Africa America, is also "knee deep" in America. The result is a language system which exploits its privileged position of "awareness" and revels in the knowledge that there is one set of people - non-African American - whose reality is based on the assumption that the society uses one system of communication and another - African Americans - who purposefully wade through that myopic view using signs which "float like a butterfly and sting like a bee."8

\section{Intentionality and speaker Responsibility}

Cultures attribute, indeed acknowledge, speech acts in ways which communicate the ideology and historical movement of the social group. Considering the complexity of the speech situation described above and the notion that speakers work within layers of meaning and through signs about signs (cf. Gates, 1988; Geertz, 1983, 1971; Volosinov, 1973), it is necessary to discuss how the African American community actually determines speaker responsibility and intentionality and "...negotiates the language user through several orders of meaning." (Gates 1988:79) 9

Kochman $(1981 ; 1986)$ addresses one aspect of intentionality 
in African American culture in his description of attitudes toward general versus categorical reference and determinate and indeterminate ambiguity. He says that for African Americans, the determination of who is being included in a reference is the responsibility of "...those whom the statement might conceivably describe (1981:90)" and not the speaker. He calls this the "If the shoe fits, wear it" rule. Kochman's conception of this rule, which assigns responsibility to the hearer (receiver), does not recognize the dialogic nature of the speech act. The speaker's role is more than that of a mere instigator for two reasons. First, the speaker's status and standing in the group is always at stake (Smitherman, 1977). Secondly, in the African American speech community (AASC), misunderstandings of message content between senders and receivers are seldom recognized as such and what is said, and all reasonable interpretations, is viewed as what is meant. speakers, therefore, are rarely viewed as innocent in terms of intent; and what a speaker may argue is a misunderstanding, is largely viewed as the hearers' understanding of what the speaker really means. This aspect of communication style is supported by Gwaltney (1979) who argues that in the AASC, "The record, that is, what anything actually is, is infinitely more important than the intent of anything $(x x i x) . "$ When he asked his informants what they thought was the difference between African Americans and whites, one replied the biggest difference is "... we [African Americans] know when we're playing" (105).

Though Kochman (1986) is correct when he says that speakers can be purposefully ambiguous, even when the speaker is not intentionally ambiguous the audience can determine intentionality and make him/her responsible for it. This is possible because counterlanguage does not exist apart from the system of American English. They both comprise, in a nonhierarchical fashion, the language and communication system of the African American speech community. They are one. Thus, while a speaker can decide to be ambiguous, as Kochman insists, the audience has "the last word" on intentionality.

This concept of intentionality then, precisely because it is part of a system which includes the reality that speakers may deny intentionality, is inextricably tied to the notion of responsibility and concomitantly, "If the shoe fits, wear it" works both ways. You are responsible for what you say as well as any consequences that may arise from saying it - whether you know it or not.

Examples of how speaker responsibility and intentionality are taught to children in the African American community have been reported by Mitchell-Kernan (1973). Below is an interaction which occurred at a family visit during my 
fieldwork.

Two girls around 8 or 9 years old burst into the house. one girl is crying loudly and holding up a bruised arm.

Girl 1 I'm sorry. I'm sorry. I'm sorry. I'm sorry, Michelle, I'm sorry.

Girl 2 (looking at girl 1's mother and crying) She pushed me on the ground in the glass! She pushed me down! She pushed me down!

Mother (to daughter) Did you push her down?

Girl 1 Yes. I'm sorry mama. I'm sorry Michelle. I didn't mean to do it.

Mother You're sorry?

Girl 1 Yes.

Mother Did you push her by accident or did you try to push her down and she fell?

Girl 1 I wanted her to trip, but not make her fall.

Mother So you meant to push her didn't you?

Girl 1 Yes.

Mother So you're not sorry that you pushed her are you?

Girl 1 (looking at the floor and speaking softly) No.

Mother see, you did something I told you not to do! Don't say you're sorry if you're not. You did it and we have to see if Michelle wants to forgive you. If I have to settle you and Michelle's problem you'll both come in here and sit down. So if you two want to play, you'd better settle it now.

Girl 1 O.K., O.K. We'll settle it. (addresses girl 2) Michelle, I pushed you and I was wrong. I was playing too hard. I didn't mean to hurt you.

Girl 2 (sobbing softly) O.K. Janice, I know. (to Girl 
I's mother) Now can we go out to play?

Mother Go on. (Morgan, 1989:98-99)

In the African American speech community the statement, "I'm sorry.", is seldom viewed as an apology. Rather, overhearers and targets of "I'm sorry." often respond with the rejoinder, "Sorry didn't do it. You did." In the above example, the mother insists that Girl 1 admit that she intended to push Girl 2 and the mother refuses to allow Girl 1 to apologize for doing something she intended to do (push Girl 2) by insisting that her daughter (Girl 1) recognize her original intention. In this case, sorry is interpreted as "didn't mean to". An acceptable apology, as shown above, is one where the speaker indicates that $\mathrm{s} /$ he actually intended to perform the ill-advised act and $s /$ he was wrong to do it. Speakers, even as children, must take full responsibility for the meaning of their words.

Communication breakdowns may occur when there is disagreement over which style of communication, counterlanguage or non-African American, is used rather than what the speaker states that $s /$ he intended to mean. It is interesting that while there can be misunderstandings over which system is in use, there is no misunderstanding over intentionality as such. Hearers seldom hold speakers who are ignorant of the counterlanguage responsible, though they often find it unbelievable that a speaker does not take responsibility for his/her words. An example of the type of problems which can arise when there is disagreement over which "system" is in operation appears in a case of "signifying" reported by Mitchell-Kernan (1971).

Barbara: What are you going to do Saturday? Will you be over here?

R: I don't know.

Barbara: Well, if you're not going to be doing anything, come by. I'm going to cook some chit'lins. (rather jokingly) or are you one of those Negroes who don't eat chit'lins?

Mary: (interjecting indignantly) That's all I hear lately--soul food, soul food. If you say you don't eat it you get accused of being saditty (affected, considering oneself superior). (matter of factly) Well, I ate enough blackeyed peas and neckbones during the depression 
that I can't get too excited over it. I eat prime rib and $\mathrm{T}$-bone because I like to, not because I'm trying to be white...

[Mary leaves]

Barbara: Well, I wasn't signifying at her, but like I always say, if the shoe fits, wear it. (p. 71)

In the above exchange Barbara both insists that she was not using the counterlanguage (signifying) while simultaneously taking responsibility for the insult. Thus the statement: "If the shoe fits wear it" is an indication that Barbara recognizes her responsibility for making the remark, whether she intended to use the system or not and whether the hearer's (researcher) or overhearer's (Mary) interpretation is what she actually meant. ${ }^{10}$

Though the speaker is responsible for hearers' interpretation of what is said, s/he is not responsible for those who participate in the exchange by a non-AASC set of rules. The Mitchell-Kernan example is a "classic" illustration of counterlanguage because all participants view intention as an outcome of using the same system. Because Barbara made a statement that was framed as counterlanguage, the hearer's could claim any reasonable interpretation they chose. In general, African Americans do not disagree with a particular reaction to what is said, but that a reaction is reasonable within a particular context. of course, agreement cannot be negotiated if there is no awareness that there is something to negotiate. In fact, denial of recognition that counterlanguage norms are in use is an important part of the negotiation of speaker intent, which is often punctuated with comments like "I didn't mean it that way." or "You took that the wrong way." " since the notion of speaker responsibility is prominent, all participants in interactions must be aware of the message content as well as social reality, context and participants (in this case participants include all hearers unless the context prohibits input from passer-bys).

The notion of speaker responsibility and intentionality in interaction described above is the basis of the following maxims which are the foundation of discourse in the AASC:

1. You should know the consequences of your statements even if you don't.

2. You are responsible for all your statements and actions - whether you know it or not 
This concept of social knowledge then, is inextricably tied to the notion of responsibility, where you are responsible for what you say as well as any consequences that may arise from saying it. This method of communication, which persists today, developed in a historical and social context of repression. It is not surprising that many of these practices continue to serve counterlanguage functions and are often "hidden" from speakers of non-African American cultures.

Because there is a sharp focus on speaker responsibility, the AASC is one where what you say you intended when you say what you say is given less credence than the overall effect or interpretation of what you actually said, which is viewed as what was really intended by the listeners. Thus the social identity of the speaker, his/her face (Goffman, 1967), is a construct of the community's perception of the speaker's role in interaction. The construction of such assessments is based on the community's notion of reality and the consequences that one faces when becoming the focus or center (as speaker) of that reality.

\section{Indirect Discourse}

African American communication style has been described as high keyed, emotional and animated (Kochman, 1981; Labov, 1974 ; Smitherman, 1977). Moreover, non-members often view the AASC's notion of direct interaction as confrontational (Kochman, 1981). Yet for women in the AASC indirect discourse, rather than direct communication, is the source of intense scrutiny and discussion and it is regularly viewed as potentially confrontational. While indirection can take many forms in discourse, there are essentially two uses which seem to be significant to the AASC: (i) pointed indirectness - when a speaker says something to someone that is either of no relevance to current or prior contexts and/or not obvious from the propositional content and (ii) baited indirectness - when a speaker says something general which is taken by the audience to be specific or addressed to someone in particular because of contextual evidence. Pointed indirectness is defined as such because it involves a "sham receiver" (Fisher, 1976) and is only recognized if background or context has been clearly established so that the intended target and those around can determine the identity of the referent. Fisher uses the following example to describe this speech act in Barbados.

A woman chose to wear an overly bright shade of lipstick to a party. She overheard a woman say, "Oh, I thought your mouth was burst." to a man whose lips were in 
perfect order. (1976: 231)

According to Fisher, the above indirect speech act is part of the communication system of Barbadian society and the subjective assessment of these events is based on societal indicators of class and status. In the U.S. however, this form of indirectness is not associated with class or status but is a sign of identity and an ideology which recognizes two realities.

Baited indirectness focuses on the features or attributes of a referent and implies that those features are also shared by the target who is among hearers and overhearers. Generally, any response regarding the referent that a hearer or overhearer makes means $s /$ he is the intended target - "if the shoe fits...". The example from Mitchell-Kernan (1972) discussed above is an example of baited indirectness, not because the speaker thinks so, (she indicates it was not intentional) but because the hearer and overhearer said that was her intention. Most reported cases of "signifying", "sounding" or "playing the dozens" are actually the "game" of baited indirectness. 12

\section{African American and White Perceptions of Intentionality and Speaker Responsibility}

A study was conducted to determine whether: (a) African American and white women have the same perceptions of intentionality in baited and pointed indirect interactions; (b) African American and white women have the same perception of speaker's and hearer's role and responsibility for what is said and whether (c) African Americans' perception of speaker's responsibility and hearer's role in determining intentionality is the same across generations. Sixty African American women and fifty-six white women between the ages of 17 and 75 were asked their reactions to two scripts containing cases of indirect discourse. The scripts were based on interactions that I have witnessed and/or participated in which foreground speaker responsibility and/or notions of intentionality. The stories were field tested over a six month period with fifteen informants who represented the ages and social class of participants of the actual study. Informants who participated in the field tests answered questions individually and then discussed the text and questions regarding authenticity, plausibility and clarity. Changes in the script were made accordingly. The majority of the suggestions supplied by the field informants to make the stories "real" and questions of responsibility and 
intentionality apparent actually complicated the story by combining acts of pointed and baited indirectness. ${ }^{13}$

\section{Regina's story}

I was talking to some close women friends of mine and another friend of mine that they hadn't met, Margaret joined us. Well, I've known Margaret for years but this was the first time that my other friends had really socialized with her. Anyway, all of my friends live in Black neighborhoods. Margaret and I happen to live in white neighborhoods. Anyway, at some point in the conversation Margaret started talking about how much she loved living outside the ghetto and away from Black people and how much better it was and how she felt that she had moved up in life, living high on the hill away from Black folk. I couldn't believe it, but I didn't say anything. Well a little later on, Margaret had already gone home, and I asked my friends if we were all still going to the movies like we planned. They all just looked at me. Then one of them said: "The way you talk, we don't know if we want to go to the movies with you." Well, I really couldn't believe that they'd get an attitude over that. ${ }^{14}$

Regina's story focuses on speaker responsibility and intentionality when Margaret reveals: "...how much she loved living outside the ghetto and away from Black people and how much better it was and how she felt that she had moved up in life, living high on the hill away from Black folk." "The hearers use pointed indirectness (directed at Regina) to register their belief that Margaret intended to insult them by stating: "The way you talk, we don't know if we want to go to the movies with you." During field testing, the informants insisted that Regina be made both the "host" receiver and the "baited" target, as a necessary addition to the story. This complication raises the question of whether Regina's friends hold her accountable for what Margaret said, and therefore the intentionality, in that they seem to be 'baiting' her to respond. It is an "If the shoe fits wear it" sequence because the reference to Regina is ambiguous; she can assume she is the target or she can ignore the ambiguity.

All informants agree that Margaret intentionally insulted the women who "live in Black neighborhoods" and she is responsible for doing so. Responses vary, however, regarding 
Regina's role and the intentionality and target of the final statement made by a hearer. Questions $1.1 \mathrm{a}$ and $1.1 \mathrm{~b}$ of Table 1 reveal the women's perceptions of what actually happened.

TABLE 1

\section{AFRICAN AMERICAN AND WHITE VIEWS OF WHAT IS SAID VERSUS WHAT IS MEANT}

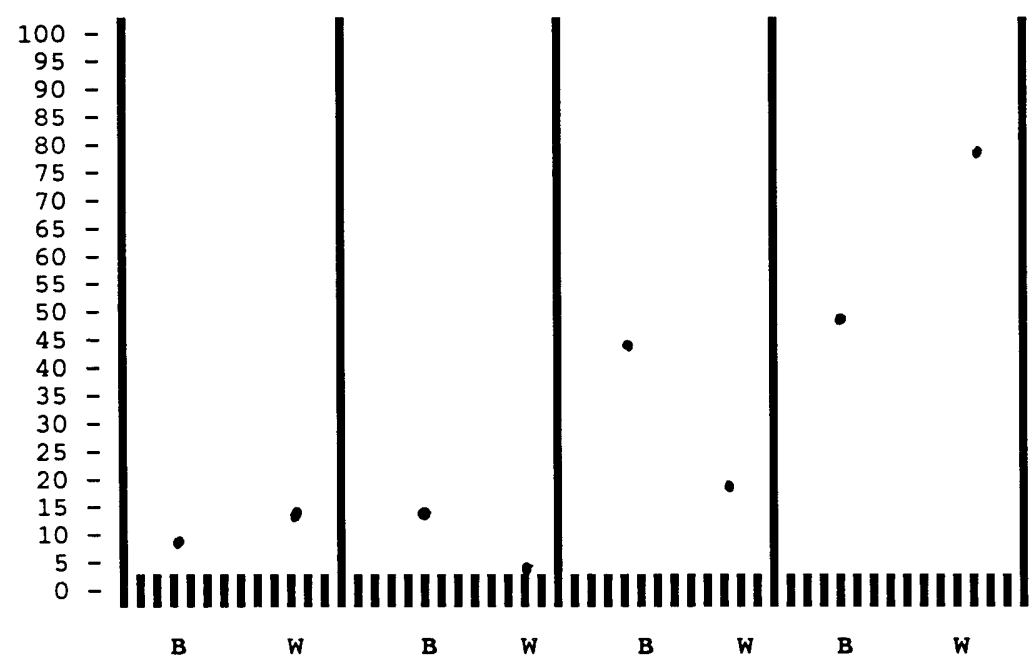

QUESTION: $1.1 \mathrm{a}$

$1.1 \mathrm{~b}$

$1.2 \mathrm{a}$

$1.2 \mathrm{~b}$

Question: $1.1 \mathrm{a}$

$1.1 b$

$1.2 \mathrm{a}$

$1.2 \mathrm{~b}$
Regina didn't say anything because she didn't agree with Margaret.

Regina didn't say anything because she didn't care one way or the other.

Regina's friends got an attitude because she didn't speak up when Margaret said what she said.

Regina's friends got an attitude because they thought she agreed with Margaret.

Though nearly all the women agree that Regina's silence during Margaret's statement does not mean that she agrees with Margaret, (only one white woman considers this a possibility), 
they are split over the meaning of her silence. Responses to questions $1.1 \mathrm{a}$ reveal that 14.28 percent of white women believed that Regina's silence may have been because she didn't agree with Margaret, though only about half ( $8.3 \%$ ) of the same number of African American women agree with them. However, only 1.78 percent (one) of the white women think Regina didn't care about what was said while 15 percent of the African American women think this was a possibility (1.1b). At the same time, the majority of both groups $(72 \%$ white and 66.6\% African American) agree that Regina was silent because she didn't want to interact with Margaret about what Margaret said.

The above responses reveal a tendency for the white informants to try to determine what the speaker meant and the African American informants to determine intentionality based on the context and possible interpretations of what the speaker said. Thus, while both groups agree that Regina didn't want to get involved, the percentage of whites who believe that Regina didn't speak up because she had an opinion that differed from her friend Margaret is nearly equal to the percentage of African American women who think Regina didn't care what Margaret said. This difference in attitude toward whether Regina was responsible for what Margaret said is echoed in the comments of one older African American test informant who both recognizes and has strong opinions about Regina's and Margaret's plight.

I hate Margaret and I hate Regina, but you don't go blaming a grown woman for something another grown woman said. I hate that. I use to be like that but I'm too old for that now.

Differences between African Americans and whites on the relationship between intentionality and responsibility in baited indirectness vary even more sharply. While only 19.64 percent of white women thought Regina's friends got an attitude because Regina didn't speak up when Margaret made her statement (1.2a), nearly half of the African American women $(43.33 \%)$ thought that was the reason for the reproach. That is, nearly half of the African American women recognized that Regina was being baited or questioned as to her intentions regarding what Margaret said. The other half (51.66\%), attributed the reproach to Regina's friend's belief that she agreed with Margaret (1.2b).

The split among the African American women is over whether to assign intentionality to Regina. In the case of $1.2 \mathrm{a}$, the women must determine if Regina is being baited since baiting is an act (sign) of intentionality. In the second case 
(1.2b), the women assign motive for the hearer's incendiary remark (what she meant) rather than determine intentionality. In contrast to the nearly even split among African American women, a full 76.78 percent of white women thought Regina's friends believed she agreed with Margaret (1.2b). Once again, when compared to whites, African Americans have a tendency to focus more consistently on the speech act (as sign) and determine the intentions of all parties accordingly while whites, who do not recognize the sign, attempt to determine what a speaker means by imbuing some psychological reason for a statement. A stronger case which supports this theory is presented in Regina's other Story.

\section{Regina's other story}

I was talking to some close women friends of mine when another close friend of mine they hadn't met, Doretha, joined us. Well, Doretha and I have been friends for years, but my other friends don't know her as well as $I$ do. Anyway, we were all sitting around talking about how our lives have changed and Doretha said "One thing I like about my life is that I don't have to have any babies if $I$ don't want to. I think any woman who has more than two kids is crazy and needs her head examined." Now, no one said anything but two of my friends have four kids a piece and one of them was pregnant with her third child. Well, a little later on, after we had been drinking and laughing a little bit, I was talking to one of the girls and Doretha was sitting nearby. So my girlfriend says very loudly so that everyone could hear "I'm sorry that I have so many kids. I guess women like me just don't have any sense and should just forget it and have our tubes tied!" I was so embarrassed that I didn't say anything.

In this story, the responses to one question in particular provide a strong case for hearers' interpretation of speaker responsibility and intentionality. When asked: "Do you think that Doretha knew that some of the women had more than two children?", 65 percent of the African American women said either yes or maybe Doretha intentionally insulted the women, while only 35.6 percent of the whites concurred.

About 55 percent of both groups thought that the woman's statement: "I'm sorry that I have so many kids. I guess women like me just don't have any sense and should just forget it and have our tubes tied!" was directed only at Doretha and 
about 44 percent of both groups thought it was directed at everybody. Moreover, when asked the motivation for the woman's statement, 80 percent of African Americans and 76.78 percent of whites thought it was because she wanted Doretha to know that she didn't like what Dortha said. An additional 23.31 percent of the whites thought she made the statement because she didn't like what Doretha said (not that she wanted Doretha to know) while 10 percent of African Americans agreed. The remaining African Americans (10\%) thought that the friend made the statement because Regina didn't say anything about what Doretha said. When asked why Regina was embarrassed, only 5 percent of whites believed it was because Regina thought the girlfriend was attacking her though five times as many African Americans (25\%) considered pointed indirectness a possibility.

Even though the number of African Americans who think Margaret was deliberately insulting the women is nearly double that of whites, there is little difference between the two groups response to interpretations of what occurred. The African American women only differ from the white women over whether they should consider the intention of the speaker and the identity of the intended target in pointed indirectness.

The discussion of Regina's other story is convincing evidence that the communication system of African American women is different from that of the white women because of the different underlying system of interpretive procedures. The African American women's responses consistently recognize that indirect reference occurred - whether what was said was an insult or not is immaterial. On the other hand for whites, the evaluation of Doretha's intention is associated with why, or how it is possible that she could insult Regina's friends. They interact on the premise that they can figure out what the speaker thinks or wants (Duranti,1990; Geertz, 1983). Yet, it is nearly impossible to determine a speaker's intention in ambiguous discourse because by definition, the speaker can claim either reality. Consequently, the African American women in the study could choose between two realities or norms while the white women only had access to one. Though the findings reported here might suggest that for African American women there are two systems of indirect discourse which are arbitrarily chosen, an intergenerational analysis reveals that the African American women are actually operating within a single multi-tiered system. 


\section{Intergenerational Differences in Interpreting Intentionality}

The responses of twenty-six of the African American women who participated in the original study were compared according to generation for Regina's story and Regina's other Story. The women were divided into three age groups: Generation I, 55-75; Generation II, 40-50; Generation III, $17-25 .^{15}$

An analysis of their responses (Table 2) reveals a striking difference between Generation I and II and Generation III regarding intentionality and responsibility in indirect discourse. When asked, from Regina's Story, whether "Regina didn't say anything because the others didn't say anything" (2.1a), only Generation III responds affirmatively. In contrast, Generations I and II respond affirmatively to the question 2.1b, "Do you think Regina didn't say anything because she didn't care one way or the other?" (100\% and $66.7 \%$ respectively), while Generation III does not consider it at a11. In question $2.2 a$, none of the Generation I women think Regina should let her friends know what she thinks about what Margaret said though Generation II is evenly divided (50\%) over this question. In contrast, a full 86.7 percent of Generation III women think Regina should have let her friends know what she thought about what Margaret said. All of Generation I and II women respond identically to question $2.3 \mathrm{a}$ though Generation III overwhelmingly ( $80 \%$ ) chooses $2.3 \mathrm{~b}$.

Table 3 shows this pattern persisting in Regina's other Story as well. Questions $3.1 \mathrm{a}$ and $\mathrm{b}$ concern whether Doretha knew that the women might have more than two children. While both of the older generations consider it very likely (100\%), the youngest group considers it unlikely a quarter of the time $(26.7 \%)$. However, when asked if Doretha might not have known about the number of children the women had (3.1c), Generation III responds in the affirmative 73.3 percent of the time though neither of the older groups consider this a possibility.

The intergenerational responses to Regina's story suggest that Generations I and II employ identical interpretive systems in determining intentionality and speaker responsibility. Generation III, however, appears to utilize an interpretive system which is more similar to the white women reported earlier (Table 1) than to older African American women. Evidence which seems to further corroborate these observations are provided in Regina's other story (Table 4). 
TABLE 2*

INTERGENERATIONAL ANALYSIS

REGINA'S STORY

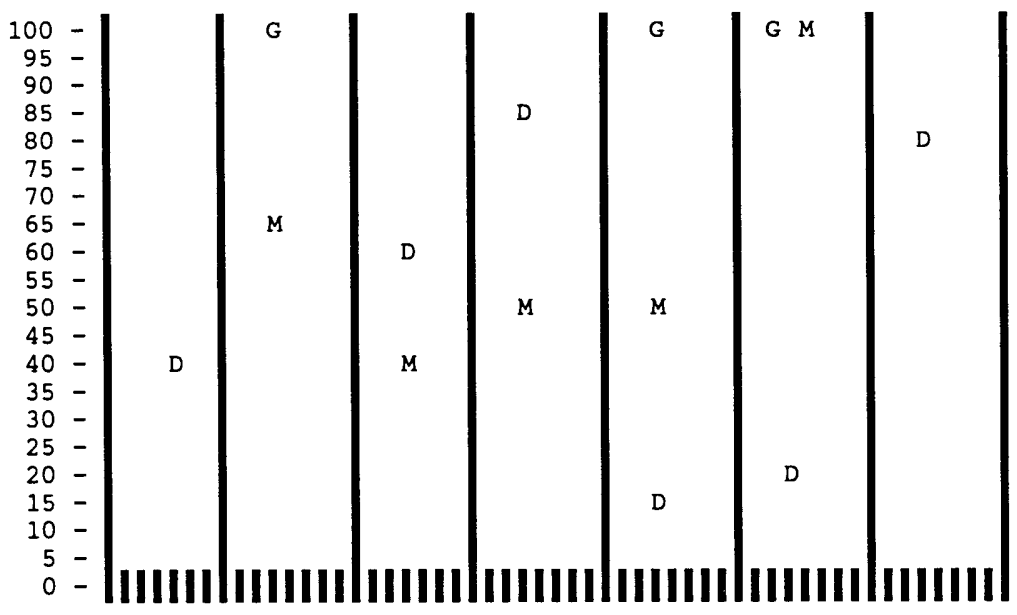

$\begin{array}{lllllll}2.1 \mathrm{a} & 2.1 \mathrm{~b} & 2.1 \mathrm{c} & 2.2 \mathrm{a} & 2.2 \mathrm{~b} & 2.3 \mathrm{a} & 2.3 \mathrm{~b}\end{array}$

Question: 2.1a Regina didn't say anything because the others didn't say anything.

2.1b Regina didn't say anything because she didn't care one way or the other.

2.1c Regina didn't say anything because she didn't want to get involved

2.2a Regina should have let her friends know about what she thought about what Margaret said.

$2.2 \mathrm{~b}$ Regina should not have let her friends know about what she thought about what Margaret said.

2.3a Regina's friends got an attitude because she didn't speak up when Margaret said what she said.

2.3b Regina's friends got an attitude because they thought she agreed with Margaret.

*G = GENERATION I $M=$ GENERATION II $\quad \mathrm{D}=$ GENERATION III 


\section{TABLE 3}

\section{INTERGENERATIONAL ANALYSIS I* REGINA'S OTHER STORY}

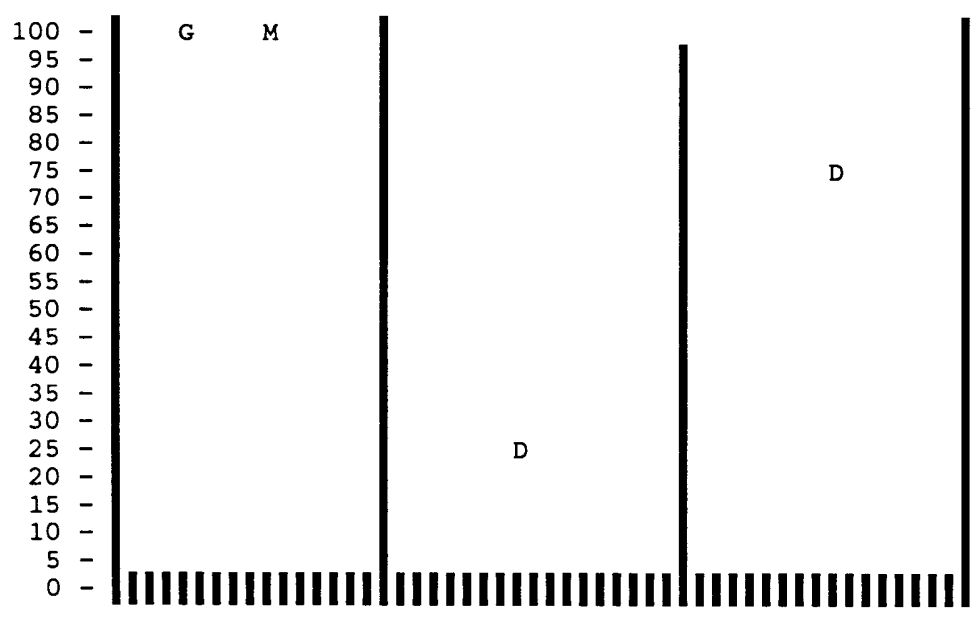

$3.1 \mathrm{a}$

$3.1 \mathrm{~b}$

$3.1 \mathrm{c}$

Question: 3.1a Doretha knew that some of the other women had more than two children.

3.1b Doretha didn't know that some of the other women had more than two children.

3.1c Maybe Doretha knew that some of the other women had more than two children.

$$
\star_{G}=\text { GENERATION I } M=\text { GENERATION II } D=\text { GENERATION III }
$$

In questions $4.2 \mathrm{a}$ and $4.2 \mathrm{~b}$, most of the younger women (65\%) believe that the woman who made the remark at the end of the story wanted Doretha to hear what she said. In contrast, all of the older women think the remark was for everyone to hear. While the younger women's focus is on the person who made the incendiary remark, the older women concentrate on the presence and role of hearers/overhearers in the interaction. This same pattern persists in response to the remaining questions $(4.3 \mathrm{a}-$ ci $4.4 \mathrm{a}-\mathrm{c}$;. Generations I and II rarely choose interpretations that might resolve ambiguity of reference or intentionality while Generation III seeks possible explanations for the ambiguity or the insensitive remark. 


\section{TABLE 4}

\section{INTERGENERATIONAL ANALYSIS* REGINA'S OTHER STORY}

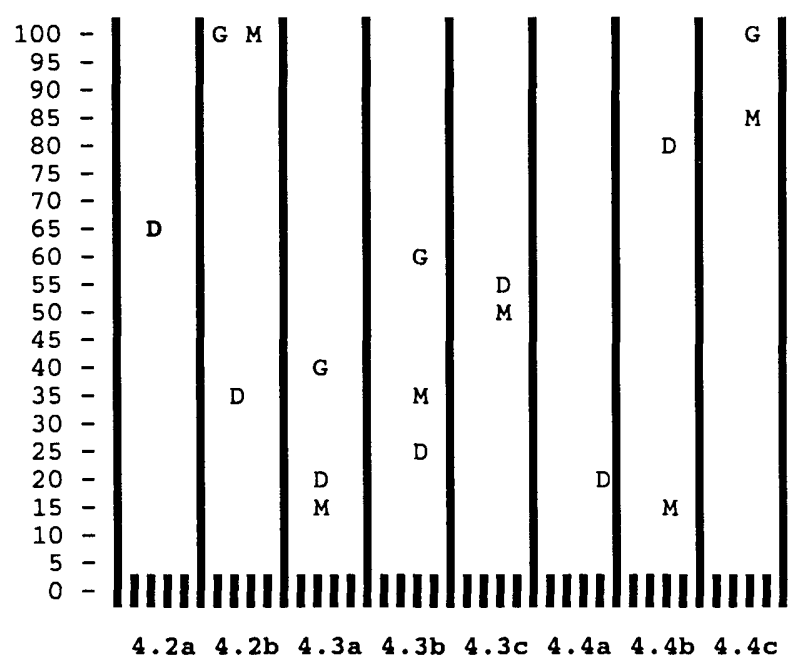

4.2a The woman wanted Doretha to hear what she said.

$4.2 \mathrm{~b}$ The woman wanted everybody to hear what she said.

4.3a The girlfriend said that to Regina because Regina didn't say anything about what Doretha said.

4.3b The girlfriend said that to Regina because she didn't like what Doretha said.

4.3c The girlfriend said that to Regina because she wanted Doretha to know she didn't like what she said.

4.4a Regina was embarrassed because of what her girlfriend said.

4.4b Regina was embarrassed because of what Doretha said.

4.4C Regina was embarrassed because she thought her girlfriend was talking to her.

*G = GENERATION I $M=$ GENERATION II $\quad D=$ GENERATION III 
The similarity in responses between the two older generations is as striking as the similarity between white women and the youngest generation. Yet the later similarity is only a superficial one. The "after survey discussion", which was insisted on by Generation III, began with "It wasn't fair." In contrast, the discussion with the white women respondents often began with "She meant..." White women in general did not seem to understand intentionality and did not support notions of speaker responsibility. Generation III, on the other hand, reported that they didn't like having to pay attention to intentionality and be responsible for "... anybody who comes along accusing me of saying something I didn't actually say." Generation III's responses appear to have been a show of solidarity for the predicament in which Regina, Margaret and Doretha found themselves rather than a lack of understanding of the speech situation. The young women, while resisting (or resenting) the system, understand its rules.

\section{Summary}

The above study has revealed that when African American and white women are compared in terms of their understanding of "what is said" in indirect discourse, the two groups have significantly different perceptions of what is intended and therefore of speaker responsibility. In cases of pointed indirectness, African Americans do not acknowledge dispensations or attempt to imbue psychological explanations for what is said. They think that what is said, including all ambiguity, is what the speaker intended. In contrast, white women consistently seek intentionality explanations for talk that is interpreted negatively. In cases which are ambiguous, they consistently attempt to resolve the ambiguity.

The difference in interpretation between races confirms the existence of two very distinct notions of communication as well as the existence of a counterlanguage. For the white women, it seems that in cases of both direct and indirect speech, what the speaker says $s /$ he 'meant' is interpreted as 'what the speaker intended to say'. It is permissible to reconstruct speaker's intentions or provide psychological explanations for possible ambiguities. African American women, however, employ an interpretive system which views individual reports of intention as one of many factors which determine intention and responsibility in indirect discourse. Because these interpretations are different, the two speech communities interpret context, role of participants, etc. in very different ways.

When African American women are analyzed according to age, 
differences between the older generations ( $I$ and II) and Generation III are evident. First, while the older generations consistently choose responses which focus on what a speaker says rather than what s/he might have meant, Generation III chooses responses which attempt to explain the intention of the speaker. Moreover, when speakers make statements whose referents are ambiguous, Generation III once again tends to provide explanations which would address the intentionality.

Generation III's interpretation of speaker responsibility invites many questions about intentionality, counterlanguage and the development of pragmatic skills in general. Yet, their responses must be viewed in conjunction with their remarks regarding responsibility and intentionality in the two stories discussed above. There are at least two possible explanations for the young women's apparent insecurity. First, since the language socialization process is ongoing into adulthood, they simply may not have command of the whole pragmatic system (cf. Schieffelin and Ochs, 1986). They may represent a level of acquisition where they recognize speaker responsibility but do not have all the interpretive skills necessary to be held accountable for it. The argument that language socialization may be incomplete is supported by African communities (Mufwene, personal communication) where, in general, speakers are not held accountable for all interpretations of intentionality until they are considered sophisticated enough to interpret indirect speech adequately and exploit context-based ambiguities. Another explanation for the young women's responses to the survey is that Generation III does not adhere to the counterlanguage and is opting for the non-African American system. They may perceive their role and relationship to society as one where "hidden" forms of discourse are unsuitable. of course, it is also possible that both of these factors contribute to Generation III's discourse insecurity. In the absence of information on speaker responsibility and intentionality in the African American community, it is impossible to determine whether their responses are an indication of language socialization, discontinuity or death.

While African American and non-African American communities make up the United States, it has always been naive to assume that communities whose histories and relationships (especially power relationships) are so different would share the same speech norms. As Hymes (1972) states, "Norms of interpretation implicate the belief system of a community (64)." African Americans in the U.S. share a reality and belief system that is both similar and very different from other speech communities. The women who migrated from the 
Western Southern states to form the urban African American community of Chicago represent the realities which were the hardships of the South and the heartbreak and dream of urban America. They have been and continue to be a rich resource in the study of the social reality of African Americans in the U.S. This paper has shown that in order to understand and fully participate in verbal interactions with the members of any speech community it is important to understand both how interactions are evaluated and the social knowledge which frames them. 


\section{FOOTNOTES}

* This paper is based on field work conducted in chicago between 1974 and 1975 and 1978 and 1982. I would like to thank the women and their families who gave their time and insights to my research and accepted me into their homes.

The idea for this paper began during post doctoral studies funded by the Minority scholar in Residence Program of the Consortium of Liberal Arts Colleges at Pomona college. Invaluable comments and discussion on earlier drafts came from Gillian Sankoff, Dell Hymes, Thomas Kochman, Claudia Mitchell-Kernan, Salikoko Mufwene, Ronald Macauley, Donald Brenneis, Bambi Schieffelin and Alessandro Duranti.

1. See Rickford (1977), Holm (1980), Baugh (1980), Mufwene (n.d.) for discussion of these issues.

2. See also Butters $(1987 ;$ 1989) for discussion of this position.

3. This is not to say that these styles should not be studied as entities in and of themselves but that they have essentially been juxtaposed with other U.S. varieties rather than analyzed in relation to the community's language communication repertoire. Thus while there is a wealth of information on speech styles like 'signifying', 'sounding' or 'playing the dozens', 'toasting' and 'rapping', little has been done on interactions that are not marked as significantly different from dominant American English varieties.

4. Halliday calls the language which develops an antilanguage and further describes it as "...the means of realization of a subjective reality: not merely expressing it, but actively creating and maintaining it. In this respect, it is just another language. But the reality is a counter-reality, and this has certain special implications. It implies the foregrounding of the social structure and social hierarchy. It implies a preoccupation with the definition and defence of identity through the ritual functioning of the social hierarchy. It implies a special conception of information and of knowledge (1978:172)."

5. Africa America refers to all persons of African descent 
residing in the Americas while African American refers to those of African descent residing in the U.S.

6. There are many more examples of the importance of indirect speech in African contexts. See especially Irvine $(1982 ; 1974)$, Piersen (1971), Herskovits (1966).

7. This style of indirectness, referred to as "dropped remarks" or "dropping words", is often considered "unruly, disruptive, stubborn, disorderly" (Reisman, 1974:123) or "rude and unmannerly" (Fisher, 1976:235). see the section on baited indirectness for further discussion of this phenomenon.

8. In light of the above discussion, it is not surprising that sociolinguists have misinterpreted or not fully understood the language behavior of African Americans. Correspondingly, in their analysis of the tense, mood and aspect system, Baugh (1984), spears (1982), and Rickford (1975), have discovered that African American English (AAE) includes items which, while identical in form to other American English varieties, have additional meaning and/or functions which are not shared. Though it is not clear whether African Americans exploit these differences, it appears that those who are not proficient in $\mathrm{AAE}$ do not recognize the differences in meaning.

9. Morgan, 1989 and Duranti, 1990 discuss the problems in western philosophy (cf.Austin, 1962, 1961; Searle, 1983, 1976, 1969; Grice 1957; 1975) regarding meaning and intentionality. These theorists discuss indirectness from the perspective of illocutionary force and attempt to develop theories about the subjective mind of the speaker. However, in many cultures (cf. Brenneis, 1986; Duranti, 1988), consequences of talk are determined through conventions which are coded, not in the message, but through knowledge of events, role, status, and ideology in ways which are conventional and recognizable.

10. Mitchell-Kernan interprets Barbara's signifying as directed to both the researcher and Mary, though Mary, the overhearer, is the only one who responds. Though the hearers are obviously offended by Barbara's remark, it is not clear that the interaction is hostile or confrontational. Ervin-Trip (1964) argues that indirect speech acts like signifying are not designed to start hostile interactions. Labov (1972), and Smitherman 
(1977) separate personal from ritual signifying and argue that personal signifying can lead to hostilities. Recently, Kochman (1986) has argued that "...the character of the activity changes from solidarity to argument with the denial rather than the introduction of personal subject matter...(154)". However, it is more likely that the difference is between baited indirectness (see below) in discourse and the "game" of signifying which is clearly marked. The "game" is over when the reference gets "too close". This often means that what is said is true or no longer a "game of indirectness". The denial is, in fact, an indication that the reference has become direct and the game has terminated or the discourse situation has changed.

11. Mary's response in Mitchell-Kernan's example of signifying illustrates this point. The focus is not on what she meant, but the choice of interpretation.

12. While I do not discuss the game of signifying here (cf. Abrahams, 1976; Kochman, 1972) it is important to distinguish verbal art from verbal strategy. Playing the "dirty dozens" reveals much about the significance of indirectness and verbal play in the African American community. It does not, however, constitute strategy in discourse because it is framed as play. Mitchell-Kernan (1973: 1971) provides additional discussion and detailed evidence which supports this analysis. Gates (1988), chagrined because the essence of "signifying" has been missed muses: "It is curious to me how many definitions of Signifyin(g) share this stress on what we might think of as a black person's symbolic aggression, enacted in language... The delightfully "dirty" lines of the dozens seem to have generated far more interest from scholars than has signifyin(g), and perhaps far more heat than light. $(68-71)$

13. During field testing, how the story was delivered (read by participant, researcher or from a tape) did not effect responses. Though there were no effects on manner in which the women reviewed the narrative and actual responses, many women asserted that they had preferences for how the story was introduced and that those preferences should be considered. In the end, all women were read the story though many also had a script to follow. A third story, "Robert's story", which demonstrates baited indirectness was included in the original study (Morgan, 1989). 
14. Though being accused of "having an attitude" or an "attitude problem" means that a person has a negative disposition, most African Americans assume that "attitude" is always a part of any interaction. toward interlocutors, the speech event, situation and is therefore essential in interpreting intentionality. Not surprisingly, controlling one's attitude, as well as the ability to determine "attitude" is considered one of the more important aspects of language socialization. It is likely that the importance of being able to "read someone like a book", can be linked to the nature of control inherent in total institutions. As Goffman (1961) notes (and described above), the process of "looping" where phases of an action are not viewed as separate but "collapsed back into the situation itself (p.37)" is a disturbing but significant aspect of total institutions. In such situations, a disposition or "attitude" toward a punishment or some action or situation may be seen as grounds for further punishment. In the American South, this is often referred to as displaying an understanding of one's "place" in society. Members of the AASC assume that speakers are able to interpret and express a range of "attitudes" which either support or contradict the actual interaction.

15. The following tables only include questions for which there are responses. For all other questions consult Morgan (1989). 


\section{REFERENCES}

Abrahams, Roger. (1976) Talking Black. Rowley, Ma.: Newbury.

Abrahams, Roger. (1970) Deep down in the jungle: Negro narrative folklore from the streets of Philadelphia. Chicago: Aldine Publishing.

Abrahams, Roger and John Szwed. (1983) After Africa: extracts from the British travel accounts and journals of the seventeenth, eighteenth and nineteenth centuries concerning the slaves, their manners and customs in the British West Indies. Connecticut: Yale University Press.

Austin, J.L. (1962) How to do things with words. London: Oxford University Press.

Austin, J.L. (1961) Philosophical papers. London: Oxford University Press.

Bailey, Guy, and Natalie Maynor. (1987) Decreolization? Language in society 16: 449-73.

Baugh, John. (1984) Steady: Progressive aspect in Black Vernacular English. American speech 59: 3-12.

Baugh, John. (1980) A re-examination of the Black English Copula. In $W$. Labov (ed.), Locating language in time and space. Philadelphia: University of Pennsylvania Press. 83-106.

Baugh, John. (1979) Linguistic style shifting in black English. Diss. U of Pennsylvania.

Berger, Peter and Thomas Luckman. (1966) The social construction of reality. London: Penguin Books.

Brenneis, Donald. (1986) Shared territory: audience, indirection and meaning. Text 6.3: 339-347.

Bryce-Laporte, Roy simon. (1971) The slave plantation: background to present conditions of urban blacks. In P. orleans \& W. R. Ellis Jr. (eds.), Race, change and urbán society. Beverly Hills, California: Sage Publication, 257-284. 
Butters, Ronald. (1989) The death of black English: divergence and convergence in black and white vernaculars. Frankfurt: Verlag Peter Lang.

Butters, Ronald R. ed. (1987) Are Black and white vernaculars diverging? Papers from the NWAVE XIV panel discussion. American speech $62: 3-80$

Dillingham, Gerald. (1981) The emerging Black middle class: class conscious or race conscious? Ethnic and racial studies. 4.4:432-451.

Duranti, Alessandro. 1990. Notes on Intentionality and Truth. Manuscript

Duranti, Alessandro. (1988) Intentions, language and social action in a samoan context. Journal of pragmatics. 12: 13-33.

Fisher, Lawrence. (1976) Dropping remarks and the Barbadian audience. American ethnologist 3.2:227-42.

Gates, Henry Louis Jr. (1988) The signifying monkey: a theory of African-American literary criticism. Oxford: Oxford University Press.

Geertz, clifford. (1983) Local knowledge: further essays in interpretive anthropology. New York: Basic Books.

Geertz, clifford. (1973) The interpretation of cultures. New York: Basic Books.

Goffman, Erving. (1974) Frame analysis. Harper Colophon: New York.

Goffman, Erving. (1961) Asylums: essays on the social situation of mental patients and other inmates. New York: Anchor Books.

Graff, Labov and Harris. (1983) Testing listeners' reactions to phonological markers of ethnic identity: a new method for sociolinguistic research. Manuscript.

Grice, H.P. (1975) Logic and conversation. In P. Cole \& J. Morgan (eds.), syntax and semantics Vol. 3: speech acts. New York: Academic Press.

Grice, H.P. (1957) Meaning. The philosophical review. 66: 377- 
388 .

Gwaltney, John L. (1980) Drylongso. New York: Random House.

Halliday, M.K. (1978) Language as social semiotic: the social interaction of language and meaning. Baltimore, Maryland: University Park Press.

Herskovitz, Melville. (1966) The new world Negro. Bloomington, Indiana: Minerva Press.

Holm, John. (1984) Variability of the English copula in Black English and its Creole kin. American speech 59.4: 291309 .

Holm, John. (1980) The creole 'copula' that highlighted the world In J. L. Dillard (ed.), Perspectives on American English. The Hague: Mouton.

Hunter, Linda. (1982) silence is also language: Hausa attitudes about speech and language. Anthropological linguistics 24.4:389-95.

Hymes, Dell. (1974) Foundations in sociolinguistics: an ethnographic approach. Philadelphia: University of Pennsylvania Press.

Irvine, Judith. (1982) Language and affect: some crosscultural issues. In H. Byrnes (ed.), Georgetown University roundtable on language and linguistics. Washington, D.C.: Georgetown University Press.

Irvine, Judith. (1974) strategies of status manipulation in the Wolof greeting. In R. Bauman \& J. Sherzer (eds.), Explorations in the ethnography of speaking. London: Cambridge University Press.

Kochman, Thomas. (1986) Strategic ambiguity in black speech genres: Cross-cultural interference in participantobservation research. Text 6.2:153-170.

Kochman, Thomas. (1981) Black and white styles in conflict. Chicago: University of Chicago Press.

Kochman, Thomas. (1972) Toward an ethnography of black American speech behavior. In T. Kochman (ed.), Rappin' and stylin' out: communication in urban black America. Chicago: University of Illinois Press. 
Labov, William (1987) Are Black and white vernaculars diverging? Papers from the NWAVE XIV panel discussion. American speech 62: 5-12, 62-74.

Labov, William. (1985) The increasing divergence of Black and white vernaculars: introduction to the research reports. Manuscript.

Labov, William. (1982) "Objectivity and commitment in linguistic science: the case of the black English trial in Ann Arbor." Language in society 11:165-202.

Labov, william. (1972) Lanquage in the inner city: studies in the black English vernacular. Philadelphia: University of Pennsylvania Press.

Labov, William and Wendell Harris. (1983) DeFacto segregation of black and white vernaculars. Paper presented at 12 th Meeting of NWAVE.

Levine, Lawrence. (1977) Black culture and black consciousness. Oxford: Oxford University Press.

Mitchell-Kernan, Claudia. (1973) Signifying. In A. Dundes (ed.), Mother wit from the laughing barrel. New York: Garland Publishing, 310-328.

Mitchell-Kernan, Claudia. (1971). Language behavior in a black urban community. Monographs of the Language-Behavior Laboratory University of California, Berkeley, Number two.

Morgan, Marcyliena. (to appear) The Africanness of counterlanguage among Afro-Americans. In $S$. Mufwene (ed.), Africanisms in Afro-American language varieties. $\mathrm{n} \cdot \mathrm{p}$.

Morgan, Marcyliena. (1989) From down south to up south: the lanquage behavior of three generations of black women residing in Chicago. Diss. University of Pennsylvania.

Mufwene, Salikoko. (n.d.) Ideology and facts on black English. In A. Spears (ed.), Lanquage, symbolism and ideology. np.

Piersen, William. (1977) Puttin' down ole massa: African satire in the new world. In D.J. Crowley (ed.), African folklore in the new world. Austin, Texas: University of Texas Press. 
Reisman, Karl. (1974) Contrapuntal conversations in an Antiguan village. In R. Bauman and J. Sherzer (eds.), Explorations in the ethnography of speaking. London: Cambridge University Press.

Rickford, John. (1977) The question of prior creolization of black English. In A. Valdman (ed.), Pidgin and creole linguistics. Bloomington: Indiana University Press, 190221 .

Rickford, John. (1975). Carrying the new wave into syntax: the case of black English bin. In R.W. Fasold \& R. W. Shuy (eds.), Analyzing variation in language. Washington, D.C.: Georgetown University Press, 162-183.

Saah, Kofi. (1984) Language use and attitudes in Ghana. Anthropological linguistics 28.3:367-77.

Schieffelin, Bambi B. and Elinor Ochs eds. (1986) Language socialization across cultures. Cambridge: Cambridge University Press.

Searle, John R. (1983) Intentionality. Cambridge: Cambridge University Press.

Searle, John R. (1976) The classification of illocutionary acts. Language in society $5: 1-23$.

Searle, John R. (1969) Speech acts: an essay in the philosophy of language. Cambridge: University of Cambridge Press.

Smitherman, Geneva. ed. (1981) Black English and the education of black children and youth - proceedings of the national invitational symposium on the king decision. Detroit: Harpo Press.

Smitherman, Geneva. (1977) Talkin and testifyin: the language of black America. Boston: Houghton Mifflin.

Volosinov, V.N. (1973) Marxism and the philosophy of language. Translated by Ladislav Mateika \& I.R. Titunik. Cambridge, Massachusetts: Harvard University Press.

Wilson, Julius, W. (1978). The declining significance of race. Chicago: University of Chicago Press.

Wolfram, Walter. 1969. A sociolinguistic description of Detroit Negro speech. Washington, D.C.: Center for Applied Linguistics. 